\title{
The Historically Changing Role of Port Rijeka in the Hungarian Context (1719-1941), with a Special View on Trieste ${ }^{1}$
}

\section{Lóránt BALI}

\author{
Vállalatökonómai és Vidékfejlesztési Tanszék, \\ Georgikon Kar, Pannon Egyetem \\ Department for Corporate Economy and Regional Development, Faculty of Georgikon, \\ University of Pannonia \\ Deák Ferenc utca, 16, 8360 Keszthely, Hungary \\ balilori@georgikon.hu
}

\section{Introduction}

The role of Rijeka was special for the respective Hungarian state. After the Hungarian conquest, the Hungarian nation constantly struggled for getting to the sea. The national history books proudly announce that in the time of Louis I. (Anjou) of Hungary, three seas washed the shores of our country. ${ }^{2}$ The nostalgic notion of "up on the sea, Hungary" became a reoccurring thought from that time on in the Hungarian social-economic life. The "[...] question of a hinterland was not only of political nature [...], but also natural barriers hindered the building of connections and their upkeep [...] (The land access problems, traffic were asserted constantly in the hinterland analysis of Hungarian geography)". ${ }^{3}$ The Adria meant the primary exit option. Since the Pacta Konventa in 1102, the Dalmatian and Croatian areas were part of the Kingdom of Hungary and thereby allowed a legitimate economic advocacy, which prevailed most intensely after the 1867-1868 Austro-Hungarian, Croatian-Hungarian Settlement (Nagodba). The aim of the study is to highlight the relationship of Rijeka and the respective Hungarian state from the starting points until today, and this is divided into periods by the most important social-economic cross points: ${ }^{4}$

1. period: period ranging from 1719 to 1867

2. period: The characteristics of the economic relation system between Rijeka and the Kingdom of Hungary in the time of Dualism

3. period: The time of Italian-Yugoslavian dichotomy

In the following, I only analyse the relevant period from the national economic point of view, which generated actual development for the city and its region, as well as from the point of view of Austrian-Hungarian Empire.

1 The resaerch was supported by the European Union and the State of Hungary, co-financed by the European Social Fund in the framework of TÁMOP 4.2.4. A/2-11-1-2012-0001 National Excellence Program, A2-MZPD-12-0113.

2 Reigned between 1342-1382. The three seas washing the shores of the Kingdom of Hungary, being a white lie, were the following: the Adriatic Sea, the Baltic Sea, and the Black Sea. Although in 1370 Hungary was in personal union with Poland, it did not become a part of the Kingdom of Hungary. Louis I (Anjou) of Hungary possessed considerable estates on the Balkans (Bosnia, Serbia), and Moldavia belonged to his supremacy, too. But neither in the case of Poland, nor Moldavia, Hungary did not have an immediate hinterland.

3 Zoltán HAJDÚ, Rijeka (Rijeka) kérdéséről, in: A Balatontól az Adriáig, Norbert Pap (ed.), Pécs 2006, $103-110$.

4 I only discuss the public law relations system changes in the study that had economic relevance. 


\section{The Period from 1719 to 1867}

The first economically relevant, important developments are linked to Charles VI (Charles III Hungarian king) Austrian emperor. He was our first ruler who carried out a conscious development politics considering Rijeka. He ensured free trade with an imperial patens in 1719 and took measures of the safety of the roads heading towards the port. In 1725, he ordered fitting and management of the free port, these measures were reasoned by the blooming Italian-Hungarian trade relations. ${ }^{5}$

His developments represented primarily imperial interests. But in this period, a dichotomy between Rijeka and Trieste started to draw out, which stemmed from their particular geopolitical location. The ruler also founded a shipping company and shipyard to counterbalance Trieste and Venice putting Rijeka into an advantageous position. Under his ruling, the Carolingian road, which was named after him, was prepared. It connected the city and Karlovac, and repaired the traffic potential of the settlement and the region. ${ }^{6}$

From the viewpoint of common law, the certificate of Maria Theresa dated on the 23 April 1779 (it was not legislated as a law) based the Hungarian dependence of Rijeka, which lifted it from the Croatian relation system. The position of the city was further strengthened by Joseph II. who created a trade district on the 20 March 1786 by the division of Severin County from the ports of Rijeka (Rijeka), Buccari (Bakar) and Portore (Portorož). The development of the sea trade was further enhanced by the additional expansion of the port's hinterland with building the Joseph road which created a connection through Karlovac to the Dalmatian and Herzegovina regions. The amendment resulted in a huge development in the city's life. In 1780, the traffic raised to its 1.5 times generated by the grain export. The tobacco processing and cloth production have arrived at the settlement, the population grew over the period of 1776-1780 from 5,132 to 8,970. The legislation of the 1779 certificate (diploma) took place in the frame of the 1807. Year IV. Code. With the 1809 Treaty of Vienna, Rijeka became a part of the Illyria province, ${ }^{7}$ created up by Napoleon until $1813 .{ }^{8}$ After the temporal Austrian supremacy from 1822, Rijeka, Buccari and the old parts of the Rijeka Regency with their new 1809 borders became parts of the Hungarian Kingdom. Following this, many harbour developments took place (deepening, quarantine harbour construction), which resulted in the constant growth in the direction of Swedish, Danish, French, Black-Sea, and Portugal colonial ports. By the 10 June 1838, the first passenger transporters had arrived, and by 1841, the first trade steamship. This way the ware could have been transported from Rijeka already to Brazil, Argentina, Chile, Africa, America and Asia (Bombay, Calcutta). ${ }^{9}$

5 Béla GONDA, A Magyar Tengerészet és a Rijekai Kikötő, Budapest 1906, 143; Zoltán Hajdú, Rijeka (Rijeka) kérdéséről, in: A Balatontól az Adriáig, Norbert Pap (ed.), Pécs 2006, 103-110.

6 Béla GONDA, A Magyar Tengerészet és a Rijekai Kikötő, Budapest 1906, 144.

7 Tamás László VIZI, Illíria a francia nagyhatalmi politikában a 19. század elején, in. Közép-Európai Közlemények $13,2011,2,7-20$.

8 The province was fully deliberated from French reign in 1813, but Francis I kept the French areal disposition, so he totally separated Hungary from the sea, the export possibilities ended up in Austrian interest. As the head of Rijeka, there was placed an Austrian Kreishauptmann, who was a subordinate of the governor of Trieste.

9 Aladár FEST, Rijeka és Magyarország, Budapest 1920, 39. 
The great achievement of the 1836 reform age parliament was the 1836 . Year XXV. Code about "the individual companies enriching State public benefit and trading, which stated that [...] Until the next Parliament, on which the Nation benefitting from lonely companies they will provide an absolutely exhaustive decision by the Legislature, a temporal statement would be made: that 1 . § Only those every individual persons, or company associations, which [...] 2 times from Pest until the Hungarian coast ferries [...] 13 times from Sisek until the Hungarian coast ferries, [...] are by this Act permitted to use water channels, trains and bridges in the advance of the Nation, or even the entire breadth generally or only some part between the line signalized by the two endpoints, who would undertake steps for the preparation at their own costs, they alone are in the preference and under the protection of using them alone". With this commandment, the Hungarian political elite created a foundation of further expansion of the Rijeka economic hinterland. This was realized at a later date, as the period from the promulgation to the Settlement was proving to be rather stormy in the Hungarian history. Croatian Ban Jelačić annexed Rijeka to Croatia on the 31 August 1848. The act did not only bring state law changes, but also put marital cases in the central marital authority in Trieste (1850), under actual Austrian control. Although, after the failure of the Bach-system after the October diploma in year 1860, the city's public opinion clearly stood by the re-annexing to Hungary, this act must have been waiting a long time. Two long decades after the reform, parliament was lost for Rijeka which could not connect into the railway system, even in this respect it has been significantly disadvantaged in comparison to Trieste. In 1857, the Trieste-Vienna main line has been opened, in 1861 the connecting Buda-Pragerhof line that guided the Hungarian products towards Trieste. The competitiveness of the city's harbour has significantly decreased, which was further degraded by the opening of the Sisek-Steinbrük line. The costs were half as high on railway than on axis. The Austrian governmental politics made the situation worse when they prohibited the creation of an independent shipping company in Rijeka because they did not want the monopole situation of the Austrian Lloyd be threatened by competitors. A permit was given only in 1856, which resulted in the Lloyd's operational area to be pushed back to the Pula-Rijeka Rijeka-Zadar lines. ${ }^{10}$

\section{The Characteristics of the Economic Relation System between Rijeka and the Kingdom of Hungary in the Time of Dualism}

The 1868. Year XXX. Code 66§ regulated Rijeka's situation regarding the Croatian-Hungarian Settlement (Nagodba), which mentioned the city as a separate body belonging to the Hungarian crown (separatum sacrea regni coronae adnexum corpus). The Croatian Sabor, the Hungarian Parliament, and the city's council conducted long discussions about the city's situation, which did not have any results. After the attempts to negotiate, the Hungarian government with the consent of the monarch approved in the July 1870 the "Rijeka provisory" regulation, with the town and district being under Hungarian control temporarily. ${ }^{11}$

10 Zoltán HAJDÚ, Rijeka (Rijeka) kérdéséről, in: Norbert PAP (ed.), A Balatontól az Adriáig, Pécs 2006, 103110; Gábor FEJÉR, Rijeka (Rijeka) közel 250 éves szerepe Magyarország külkereskedelmében, in: Földrajzi Közlemények 133, 2009, 2, 147-157; Aladár FEST, Rijeka és Magyarország, Budapest 1920, 39.

11 Zoltán HAJDÚ, Rijeka (Rijeka) kérdéséről, in: Norbert PAP (ed.), A Balatontól az Adriáig, Pécs 2006, 103-110; Simonné P. PALLOS, Leghőbb vágyam Fiuméba kerülni ... Magyar iskolák Fiuméban, Kaposvár 2012, 346. 
With the normalization of the common law situation, Rezső Havass was among the first to recognize - emerging from the Hungarian scientific and economic life - the importance of developing trade and transport connections. More alternatives were published from the viewpoint of the Hungarian Empire. "The Hungarian economy and power aspirations' compass points east. Not only the glorious past, the tradition of the House of Arpad's, the Anjou's and King Matthias' global policy stimulated us to this pursuit but the whole chain of our interests - especially in economic field - make our most important assignment to encapsulate the east, especially the neighbouring Balkan Peninsula."12

His first significant essay has been published in this topic about the role of Karlovac-Rijeka railway in the Hungarian national economy. From this time on, the scientific representation of imperialistic attempts has been on the agenda in the analysis of the issue of reaching the Adriatic region. ${ }^{13}$

The railway connection between the harbour and Budapest was an indispensable pledge for the trade development of the city. By the autumn 1873, the linking section between Karlovac and Rijeka as a part of the Plains-Rijeka main line, and with this the city was connected to the blood line of the railway traffic. By the end of the period, 60 kilometres of track system have been built serving the railway station and the harbour. Between 1867-1918, the Hungarian governments invested 55 million crowns (korona) into the city. Gábor Baross, Minister of Transportation, created the budget opportunities of rail-road network-port triple development while keeping the nation's economic interests in mind. As a result, the port's cargo traffic in 1913 reached 2.1 million tons, reached the $10^{\text {th }}$ place in the rankings of ports of Europe, despite the unfavourable natural conditions, as a result of public investment, the competitiveness has been established. The 1880. Year XXV. Code about the establishment of normal steam ship connection between Rijeka and the West-European ports created that with public subsidy with the name of "Adria-SteamShip-Company", it could be connected into the West-European traffic. In 1891, the free status of the port is expired, stepping into the Austrian-Hungarian common duty zone. The years of dualism had a positive impact on the port, the population present in 1869 was 17,884 , which by 1910 grew to 49,726 . The rate of Hungarian population was $20 \%$, Croatian 25\%, Italian 51\%. So, when on 29 October 1918 Lajos Jelkefalussy, the last Hungarian governor left Rijeka, he left an advanced, multi-ethnic city behind. ${ }^{14}$

\section{The Time of Italian-Yugoslavian Dichotomy}

Before the First World War, the ethnic "fermentation" processes had started. Three major political directions were to be found. "Giovane Rijeka" irredenta Italian movement, the one lead by Frano Supilo being first directed to Hungary, then towards a Serbian-Croatian cooperation; and the Autonomist Party lead by Ricardo Zanella. From these three directions,

12 Rezső HAVASS, Magyarország és a Balkán (Szerbia, Bulgária, Románia) Gazdaságpolitikai tanulmány, in: Földrajzi Közlemények 41, 1913, 4-6, 153-199.

13 Albert PÉCSI, Havass Rezső emlékezete, in: Földrajzi Közlemények 55, 1927, 5, 81-83.

14 Zoltán HAJDÚ, Rijeka (Rijeka) kérdéséről, in: Norbert PAP (ed.), A Balatontól az Adriáig, Pécs 2006, 103-110; Norbert PAP, A magyar-olasz kapcsolatok földrajzi dimenziói, in: Földrajzi Értesítő 61, 2007, 3-4, 303-332. 
the one by Zanella seemed to overcome the others. Zanella's recognition that Rijeka should be an autonomous port with the hinterland ensured by the independence could not have been fulfilled, as the power struggle favoured the Italian irredentism in the end. ${ }^{15}$

The agreement made by Pašić and Mussolini on the 27 January 1924 in Rome settled the questions concerning Rijeka, the city was annexed to Italy. But a more favourable fate was given to the port of Sušak, being part of Rijeka, but annexed to the Serbian-Croatian-Slovenian Kingdom..$^{16}$ In the new state, it could form a new hinterland for itself. It could partly fulfil the need for the Serbian sea access within the new state form. But the new dichotomy left their mark on the economic situation of the port. ${ }^{17}$

After the cataclysm, the situation was formed adversely in Rijeka, Trieste became his rival in the Italian state space. This entailed practically the validation of the Italian sole interests, as Trieste remained the primary port in the Adriatic; in any case it should be noted that both of them lost in significance. After the dissolution of the Austro-Hungarian Monarchy, they left without a hinterland, the background necessary for a successful economy operation was lacking which was destroyed after the Treaty of Trianon. The Italian-Hungarian Treaty of Eternal Friendship signed in 1927 did not cause any increase in traffic in the harbour. Both ports have never been again able to reach the traffic before the First World War, not even together. ${ }^{18}$

After the cataclysm, from the past squadron of "Adria" Magyar Királyi Tengerhajozási RT ("Adria" Royal Hungarian Sea Nav. Co. Ltd.) just twenty-five ships returned. From the acquired shares of the discontinued company, there was the "Societá di Navigazione Marittima anonima Adria" Association set up. So from 1924, Rijeka has been the responsible port again of the company with Hungarian interest which operated until December 1936. Boat fleet was taken over by the "Tirrenia" shipping company that operated until the end of the Second World War. Between the two world wars, Rijeka port had 137 steam ships and 93 passenger ships. Sušak (port city of Rijeka) timber export sales rivalled those of Western European and North American ports. ${ }^{19}$

\section{Abstract}

From 1779 until the period between the two World Wars Rijeka had a long way of history. Several times prevented by Austrian imperial interests against Trieste but with strong support from Hungary a major port even with European scale could have been constructed by

15 László GULYÁS - Lóránt BALI, The Rijeka Question 1918-1920, in: ÖT KONTINENS, az Új- és Jelenkori Egyetemes Történeti Tanszék tudományos közleményei, Budapest 2012, 143-151.

16 Edit LŐRINCZNÉ BENCZE, Trianon és Magyarország déli határrégiói, in. Közép-Európai Közlemények 3, 2010, 4, 69-76.

17 László GULYÁS, A Horthy-korszak külpolitikája 1. Az első évek 1919-1924, Máriabesenyő 2012, 179; Árpád HORNYÁK, Magyar-Jugoszláv diplomáciai kapcsolatok 1918-1927, Pécs 2004, 355; Bogdan KRIZMAN, Italija u politici kralja Alexandra i kneza Pavla (1918-1941), in: Časopis za suvremenu povijest, 1, 1975. 77-86.

18 László GULYÁS, Küzdelem a Kárpát-medencéért. Kárpátia. Stúdió Budapest 2012, 283.

19 Gábor FEJÉR, Rijeka (Rijeka) közel 250 éves szerepe Magyarország külkereskedelmében, in: Földrajzi Közlemények 133, 2009, 2, 147-157. 
the end of the $19^{\text {th }}$ century that successfully served the Hungarian imperial interests, and became a Hungarian sea exit. The peculiar public law relations did not constitute an obstacle to economic development. However, the great power rivalries sealed the fate of Rijeka. It became loser of the period between the two World Wars. The city's fate was resolved after the Second World War, when it returned to the South Slav state.

\section{Keywords}

Hungary, Rijeka (Fiume), dualism, Rijeka (Fiume) - Trieste dichotomy 